\title{
POLITYKA KSIĘŻNEJ GRYZELDY W ORDYNACJI ZAMOJSKIEJ W LATACH 1666-1669
}

\section{Duchess Gryzelda's policy in the Zamoyski Family Fee Tail in 1666-1669 \\ Abstract}

Duchess Gryzelda Wiśniowiecka took over the Zamoyski Family Fee Tail at the end of 1665. She relied on a stable political background, however, simultaneously she tried to win the inhabitants of the estate. There was propaganda on its territory. Also, the Duchess' court carried out a limited control of the correspondence that was created on the premises of the estate. The confirmation of Wiśniowiecka's stable rule is her attitude towards leaseholders. She enforced all payments in a strict manner. The number two person in the estate was ensign Hieronim Żaboklicki of Bracław. After the convocation Sejm of 1668, Michał Korybut Wiśniowiecki began to gain more and more importance.

Keywords: Gryzelda Wiśniowiecka, the Zamoyski Family Fee Tail, policy

\begin{abstract}
Abstrakt
Księżna Gryzelda Wiśniowiecka przejęła Ordynację Zamojską pod koniec 1665 r. Opierała się na stabilnym zapleczu politycznym. Jednocześnie starała się jednak zjednać sobie mieszkańców Ordynacji. Na jej terenie cały czas funkcjonowała propaganda. Dwór księżnej prowadził także ograniczoną kontrolę powstającej na terenie Ordynacji korespondencji. Potwierdzeniem prowadzenia przez G. Wiśniowiecką stabilnych rządów jest jej stosunek do arendarzy. Wszelkie należności egzekwowała od nich w sposób surowy. Osobą numer dwa w Ordynacji był chorąży bracławski Hieronim Żaboklicki. Po sejmie konwokacyjnym 1668 r. coraz większe znaczenie zaczął zdobywać Michał Korybut Wiśniowiecki.
\end{abstract}

Słowa kluczowe: Gryzelda Wiśniowiecka, Ordynacja Zamojska, polityka

Toczący się w latach 1665-1677 spór o Ordynację Zamojską - jeden z większych majątków I Rzeczypospolitej - był istotnym konfliktem politycznym w omawianym okresie. Do walki o spadek po zmarłym bezpotomnie 7 kwietnia 1665 r. Janie „Sobiepanie” Zamoyskim stanęli: jego żona Maria Kazimiera d'Arquien (wraz z drugim mężem Janem Sobieskim), siostra

\footnotetext{
Marek Groszkowski - e-mail: mgroszkowski1@gmail.com.
} 
byłego ordynata Gryzelda Konstancja Wiśniowiecka wraz z synem Michałem Korybutem i siostrzeńcem Stanisławem Koniecpolskim i wreszcie boczna linia Zamoyskich, reprezentowana przez kasztelana czernihowskiego Zdzisława Jana Zamoyskiego i jego syna podstolego lwowskiego Marcina. Ta ostatnia, zgodnie ze statutem Ordynacji, a także ostatnią wolą zmarłego III ordynata - miała pełne prawo do jej dziedziczenia. Nie uznawały go jednak pozostałe strony sporu. Wspomniany konflikt zajmował nie tylko liczne sprawy w sądach i trybunałach, ale też obrady niemalże wszystkich sejmów i sejmików z lat 1665-1677. Tylko zgromadzenie parlamentarne mogło rozstrzygnąć tę rywalizację na drodze legalnej.

Księżna G. Wiśniowiecka, po zbrojnych walkach z Zamoyskimi, przejęła Ordynację pod koniec 1665 r. Choć nie miała na to zgody Rzeczypospolitej, to faktycznie zarządzała nią do swojej śmierci, która nastąpiła siedem lat później². Uzurpowała więc sobie w ten sposób uprawnienia ordynatów zamojskich. Prowadzona przez księżną polityka na terenie tytułowego majątku nie została dotychczas omówiona w literaturze przedmiotu. Bardzo krótki fragment poświęciła jej jedynie Ilona Czamańska³ 19 czerwca 1669 r. Michał Korybut Wiśniowiecki został wybrany na króla w Rzeczypospolitej. To wydarzenie zmieniło nie tylko sposób zarządzania Ordynacją, ale także znaczenie rywalizacji o nią. Dlatego też stanowi górną cezurę niniejszego artykułu.

W celu pełnego zrozumienia założeń polityki księżnej niezbędne jest przedstawienie zaplecza, na którym G. Wiśniowiecka opierała swoje rządy w Ordynacji. Informacji na ten temat dostarczają trzy dokumenty. Pierwszym z nich jest testament wdowy po Jeremim Wiśniowieckim. Drugim - protest przeciwko M. Zamoyskiemu złożony przed przedstawicieli miast Ordynacji na początku 1666 r. Trzecim wreszcie - oblata dekretu Trybunału Koronnego Lubelskiego między spadkobiercami „Sobiepana” a starostami: lwowskim, przemyskim i halickim. Nie można także zapominać o diariuszu Bazylego Rudomicza ${ }^{4}$. Jest to źródło, które zawiera niezbędne dla niniejszego opracowania informacje.

W swoim testamencie księżna jako tych, którym „względem nagrody zasług różnie zasłużonym dworu", wymienia w pierwszej kolejności chorążego bracławskiego Hieronima Żaboklickiego. W dalszej natomiast są to: profesorowie Akademii Zamojskiej ks. Jan Unikowski i ks. Andrzej Abrek, ekonom klasztoru franciszkanów w Szczebrzeszynie Nikodem Gawarecki, sędzia ziemski lubelski Jerzy Szornel, wójt wsi Brody pod Zamościem Kazimierz Kuchowicz, Andrzej Romaradzki i rajca zamojski Śnitowski ${ }^{5}$. Wszystkie wymienione osoby należały do bliskich współpracowników księżnej. Do Gawareckiego księżna przynajmniej kilka razy pisała w sprawach administracyjno-gospodarczych, prosząc go o wypłatę

\footnotetext{
M. Chmielewska, Sejm elekcyjny Michała Korybuta Wiśniowieckiego 1669 roku, Warszawa 2006, s. 175-176.

I. Czamańska, Wiśniowieccy. Monografia rodu, Poznań 2007, s. 226.

Ibidem.

4 B. Rudomicz, Efemeros czyli diariusz prywatny pisany w Zamościu w latach 1656-1672, cz. 2, 1665-1672, oprac. W. Froch, M. L. Klementowski, Lublin 2002, passim. Więcej o B. Rudomiczu zob. R. Leszczyński, Rudomicz Bazyli, w: Polski Stownik Biograficzny, t. 32, Warszawa 1991, s. 664-666.

5 Testament Gryzeldy Konstancji z Zamoyskich Wiśniowieckiej z 1672 roku, oprac. K. Przyboś, „Genealogia”, 2003, t. 15, s. 101-102. Więcej o N. Gawareckim i K. Kuchowiczu zob. ibidem, s. 106, przyp. 21 i 22. O postawie politycznej J. Szornela zob. M. Sokalski, Między królewskim majestatem a szlachecka wolnością. Postawy polityczne szlachty małopolskiej w czasach Michała Korybuta Wiśniowieckiego, Kraków 2002, s. 27. Imienia Śnitowskiego nie udało się ustalić.
} 
należnych pieniędzy czy innych ekwiwalentów (np. owsa) różnym osobom ${ }^{6}$. Romaradzki zaś służył w chorągwi J. Zamoyskiego7.

We wspomnianym powyżej proteście są wymienieni: miecznik chełmski i posiadacz Tarnogrodu, Bieszczy oraz Księżpola Aleksander Garczyński, cześnik bełski i posiadacz Tomaszowa Wojciech Tomisławski, posiadacz Zamchu Jan Rzepecki, a także posiadacz Krzeszowa Jan Słoniewski. Ponadto są tam podane imiona i nazwiska ok. 40 osób, które razem z księżną złożyły protest przeciwko Zamoyskim ${ }^{8}$. Można ich zatem także zaliczyć do jej stronników.

W oblacie dekretu trybunalskiego, oprócz osób wspomnianych z imienia i nazwiska, jako zwolennicy księżnej Gryzeldy są też podani: wojski buski Adam Czarnołuski (zmarł w 1668 r.), cześnik bełski Andrzej Chojnacki, Andrzej Berezowski i Stanisław Pruszkowski ${ }^{9}$. B. Rudomicz do grona najbliższych zwolenników księżnej zalicza ponadto podskarbiego zamojskiego Macieja Antoniego Wacławowicza, który za czasów „Sobiepana” posiadał bardzo wysoką pozycję na dworze zamojskim. Pamiętnikarz wspomina także o chorążym lubelskim Sebastianie Strońskim, który odznaczał się przenikliwością polityczną ${ }^{10}$. Postawę przychylną księżnej przybrał także sam B. Rudomicz ${ }^{11}$. Listę osób związanych z księżną Gryzeldą uzupełniali ,przydatni w działaniach propagandowych pracownicy akademii i członkowie kanonii zamojskiej oraz wykorzystywani do bardziej sekretnych misji słudzy i dworzanie" 12 .

Na terenie Ordynacji żyło zatem przynajmniej ok. 60 osób, które czynnie wspierały księżną w trakcie jej rządów w majątku. Reszta biernie pogodziła się z faktami. G. Wiśniowiecka cieszyła się dość sporym respektem w społeczeństwie Rzeczypospolitej. Przyjmowała np. obcych posłów, jak chociażby wysłannika tatarskiego w grudniu 1667 r. ${ }^{13}$. Powszechny był niewątpliwie pogląd wyrażony przez burgrabiego zamojskiego Stanisława Borkowskiego. Jego zdaniem w razie zwycięstwa Zamoyskich w omawianym sporze poddani Ordynacji zostaną oskarżeni o współpracę z księżną. Lepiej już zatem wspierać wdowę po J. Wiśniowieckim, niż dopuszczać do kolejnej zmiany zarządzającego Ordynacją, co oznaczałoby niewątpliwie przynajmniej chwilową destabilizację sytuacji politycznej w majątku. Wystarczającym potwierdzeniem popularności tej opinii niech będzie cytat z dzieła B. Rudomicza:

6 G. Wiśniowiecka do N. Gawareckiego, Zamość 29 VI 1666, b. d., Zamość 14 XI 1671, Archiwum Główne Akt Dawnych w Warszawie (dalej: AGAD), Archiwum Zamoyskich (dalej: AZ) 1002, s. 1-5.

$7 \quad$ K. Przyboś (Testament Gryzeldy..., s. 106, przyp. 31) mylnie utożsamia Romaradzkiego z B. Domaradzkim. Zob. przywilej dla A. Romaradzkiego, Warszawa 17 V 1672, AGAD, AZ 2595, s. 62.

8 Protest przeciwko Zamoyskim złożony przez przedstawicieli miast Ordynacji, Krasnystaw 6 I 1666, AGAD, AZ 2379, s. 110. Tomisławski był osobą związaną z Wiśniowieckimi. Więcej na jego temat zob. Testament Gryzel$d y \ldots$, s. 107 , przyp. 52 i 53.

9 Oblata dekretu Trybunału Koronnego Lubelskiego, Centralnyj Derżawnij Istorićnij Archiv Ukraini we Lwowie, f. 9, op. 1, ks. 420, s. 5. Informację o śmierci A. Czarnołuskiego podaje B. Rudomicz, op. cit., s. 173.

10 B. Rudomicz, op. cit., s. 276, 294, 351. P. Tyszka (Maria Kazimiera d'Arquein Zamoyska, czwarta ordynatowa zamojska, w: Maria Kazimiera Sobieska (1641-1716). W kręgu rodziny, polityki i kultury, red. A. Kalinowska, P. Tyszka, Warszawa 2017, s. 17) uważa, iż M. A. Wacławowicz za czasów „Sobiepana” był drugim w hierarchii zamojskich urzędników. Zob. też listy G. Wiśniowieckiej do M. A. Wacławowicza, Warszawa 1668-1669, AGAD, AZ 1019, s. 1-18

11 Na początku 1666 r. złożył on życzenia noworoczne księżnej, ofiarowując przy tym biały chleb i wino, zob.

B. Rudomicz, op. cit., s. 61 .

12 J. Matyasik, Obóz polityczny króla Michała Korybuta Wiśniowieckiego, Warszawa 2011, s. 45.

13 B. Rudomicz, op. cit., s. 168. 
„Jeżeli Pan z nieba nie zechce ocalić nienaruszalności stanu Zamościa, to upadnie z powodu gnębicieli nie tylko lud, ale także osoby należące do Akademii’"14. Pogląd ten był jednak połączony z niepewnością i świadomością, że rządy księżnej nie są usankcjonowane prawnie i praktycznie w każdej chwili może nastać ich koniec ${ }^{15}$.

G. Wiśniowiecka starała się rządzić twardą ręką i nie zawsze trzymała się obowiązujących wcześniej w Ordynacji reguł. W marcu 1666 r. wprowadziła dla piekarzy zamojskich obowiązek zakupu zboża pochodzącego tylko i wyłącznie $\mathrm{z}$ terenów majoratu. W razie niezastosowania się do tego postanowienia zastrzegła sobie prawo zamknięcia piekarni winowajcy ${ }^{16}$. Twarde rządy miały w założeniu zalegalizować w oczach poddanych jej władzę nad Ordynacją i zapobiec ewentualnym przestępstwom albo wystąpieniom wewnętrznym. Trzeba też pamiętać, iż w oczach dworzan, sług, klientów rodu Zamoyskich, czy wreszcie pozostałych mieszkańców Ordynacji, funkcjonował obraz ordynatowych jako silnych matron - nie tylko kochających i oddanych żon oraz matek, ale przede wszystkim dobrych gospodyń, które w obliczu kryzysu potrafiły wziąć na siebie odpowiedzialność za aktualne losy i przyszłość latyfundium ziemskiego oraz lokalnej społeczności ${ }^{17}$. Gryzelda Wiśniowiecka starała się wpisać w ten schemat i czyniła to z powodzeniem.

Było to dla niej tym ważniejsze, iż przez cały czas jej rządów nad Ordynacją Zamoyscy bynajmniej nie zamierzali poddawać się i konflikt o omawiany majątek trwał nadal. Stąd też księżna musiała zadbać o to, by na terenie majoratu nie narodziła się opozycja przeciwko niej. B. Rudomicz odnotował pod datą 22 maja 1666 r., iż rektor Akademii Zamojskiej Jan Sieprawski „był podejrzany z powodu rozmowy z [...] (Zdzisławem - M.G.) Zamoyskim”. Niepewnie mógł czuć się także sam autor pamiętnika, którego oskarżano o dopuszczanie do współpracy z kasztelanem czernihowskim jego żony ${ }^{18}$.

Z.J. Zamoyski przynajmniej przez większość omawianego okresu przebywał na terenie Ordynacji, co niewątpliwie było przysłowiową „,solą w oku” wdowy po J. Wiśniowieckim. Wobec tego cały czas aktywnie działała tam propaganda skierowana przeciwko Zamoyskim. Ulegali jej nawet ludzie z niższych warstw społecznych. W trzeciej dekadzie maja $1666 \mathrm{r}$. sługa niejakiego Krasowskiego publicznie obraził kasztelana czernichowskiego. Na żądanie Z.J. Zamoyskiego został on wprawdzie aresztowany, jednak z polecenia wujka Krasowskiego - burgrabiego zamojskiego S. Borkowskiego - wypuszczono go. Wobec tego kasztelan czernihowski złożył protest do Trybunału Koronnego. S. Borkowski wówczas jawnie działał w interesie księżnej Gryzeldy. Jego zdaniem, gdyby Ordynacja utrzymała się i zgodnie z jej statutem została przyznana Zamoyskim, to musiałby „odejść z niczym”"19. Wniesiony przez kasztelana czernihowskiego pozew został jednak anulowany w związku z tym, iż on sam został niebawem skazany przez Trybunał Koronny Lubelski ${ }^{20}$. Jeszcze zanim to nastąpiło,

\footnotetext{
14 Ibidem, s. 94-95.

15 „Łatwo pojąć, jakiego należy się spodziewać porządku, jeśli Ordynacja przez dłuższy czas nie będzie obsadzona", ibidem, s. 100.

16 Ibidem, s. 72; I. Czamańska, op. cit., s. 227.

17 Na taki wizerunek pracowały Barbara z Tarnowskich wraz z Katarzyną z Ostrogskich. Zob. P. Tyszka, op. cit., s. 13.

18 B. Rudomicz, op. cit., t. 2, s. 94.

19 Ibidem, s. 94-95.

20 Oblata dokumentu w sprawie Z. J. Zamoyskiego, 1666, Archiwum Państwowe w Lublinie (dalej: APL), księgi grodzkie krasnostawskie, Relacje - Manifestacje - Oblaty 5, k. 267-268v.
} 
księżna starała się kontrolować każdy jego ruch. Ograniczyła liczbę osób, z którymi mógł się swobodnie spotykać 21 .

Rudomicz wspomina także o kontrolowaniu korespondencji przez ówczesny dwór zamojski. Jego zdaniem takiej cenzurze podlegał np. list adresowany do niego, a pisany przez stolnika lwowskiego Floriana Orchowskiego. Sam autor diariusza przyznał, że wszystkie listy mimo tych problemów dotarły we właściwe miejsce ${ }^{22}$. Jeśli nawet korespondencja była faktycznie sprawdzana, to na pewno jej inwigilacja nie osiągnęła poziomu znanego z późniejszym epok historycznych.

Potwierdzeniem prowadzenia przez księżną rządów silną ręką jest jej stosunek do arendarzy. Wszelkie należności egzekwowała od nich bardzo surowo. Osobiście pilnowała, by wpłacali je w terminie. Tak było np. w przypadku niejakiego Józefa, który arendował od G. Wiśniowieckiej młyny w Szczebrzeszynie. Sprawą spłaty przez niego zaległego czynszu księżna interesowała się nawet podczas swojego pobytu w Warszawie. Prosiła M.A. Wacławowicza o wyegzekwowanie od arendarza 234 zł tytułem opłaty za niego i 156 zł za jego żonę ${ }^{23}$.

Mimo twardej polityki księżnej nie udało się zapobiec różnego rodzaju wykroczeniom. Według B. Rudomicza były one udziałem przede wszystkim żydów. Jako przykład podaje on zdarzenie, które miało miejsce 7 marca 1666 r. w Fajsławicach, gdzie odbywał się pogrzeb młynarki. Pewna żydówka miała skropić krwią drogę, którą przeszedł następnie kondukt pogrzebowy ${ }^{24}$. Prawdopodobnie autor diariusza nie ma jednak racji i przestępczość wśród żydów nie miała charakteru masowego, gdyż musiało by się to doczekać oficjalnej reakcji ze strony G. Wiśniowieckiej, a takiej nie ma w żaden sposób udokumentowanej. Wydaje się, że wdowa po J. Wiśniowieckim w latach 1666-1669 nie represjonowała ludności żydowskiej, co być może miało związek z dość znaną działalnością lekarzy żydowskich na terenie Ordynacji ${ }^{25}$. Przykładem pozytywnej działalności księżnej wobec wyznawców religii mojżeszowej może być dekret z 18 stycznia 1666 r. Na jego mocy księżna przyznała żydowi Józefowi Izraelowiczowi 663 złote i 9 groszy tytułem zwrotu za zbyt dużą zapłaconą przez niego daninę ${ }^{26}$. Nie oznacza to jednak, że nie wydano wówczas żadnych ustaw antyżydowskich. Na przykład w październiku 1668 r. zakazano żydom arendować gorzelnie na przedmieściach miast ordynackich ${ }^{27}$. Te rozporządzenia miały na celu zmotywować ludność wyznania mojżeszowego do sumiennego wywiązywania się ze swoich obowiązków, co też żydzi starali się czynić ${ }^{28}$.

G. Wiśniowiecka miała także wpływ na zamojską hierarchię kościelną. Warto przypomnieć, iż aktywnie popierali ją tacy przedstawiciele duchowieństwa jak J. Unikowski i A. Abrek. Za ich cichą aprobatą niejednokrotnie nominowała proboszczów w parafiach Ordynacji. Miało to miejsce np. 20 lutego 1666, kiedy to z jej nadania zwierzchnikiem

\footnotetext{
21 B. Rudomicz, op. cit., s. 99.

22 Ibidem, s. 99-100.

23 G. Wiśniowiecka do M.A. Wacławowicza, Warszawa 11 IV 1668, AGAD, AZ 1019, s. 6.

24 B. Rudomicz, op. cit., s. 73.

25 Więcej o niej zob. W. Partyka, Żydowscy lekarze i cyrulicy w Ordynacji Zamojskiej w XVII-XVIII w., „,Kwartalnik Historii Żydów", 2008, nr 2(226), s. 313-317.

26 Rozporządzenie księżnej Gryzeldy, Zamość 18 I 1666, AGAD, AZ 2750, s. 189.

27 B. Rudomicz, op. cit., s. 199.

28 Zob. oświadczenia żydów zamojskich, Zamość 20 IV 1667, APL, Akta miasta Zamościa 127, s. 11-14.
} 
kościoła w Biszczy został Hrehory Tyczoniowic ${ }^{29}$. Całą procedurę przyznawania wakujących probostw opisuje B. Rudomicz. W lipcu 1668 r. tego typu stanowisko zwolniło się w Łukowej. Wówczas podania w sprawie prezenty na to stanowisko złożyli księża: Andrzej Kurowski, Michał Wielkowicz, Jan Chryzostom Budzyński i Ignacy Gryglicki. Spośród tych kandydatów G. Wiśniowiecka wybrała A. Kurowskiego. Przy tej „rekrutacji” doradzał jej J. Unikowski ${ }^{30}$. Wdowa po J. Wiśniowieckim ingerowała także w sprawy bractwa cerkiewnego. I tak w październiku 1668 r. z jej inicjatywy starsi tego zakonu Franciszek Ferenty i niejaki Dubowicz zostali skazani przez Sąd Komisarski Zamku Zamojskiego na pięć dni aresztu i zapłacenie dziesięciu grzywien, gdyż chcieli przyjąć Michała Gunaszowskiego w poczet członków bractwa bez uzyskania zgody G. Wiśniowieckiej. Zobowiązali się w przyszłości przedstawiać księżnej każdego nowego kandydata ${ }^{31}$.

Władza księżnej w zakresie spraw kościelnych nie była jednak absolutna. W maju $1667 \mathrm{r}$. jeden z franciszkanów - o. Michał Franciszek Występ - został przeniesiony do Lwowa. W tym wypadku protesty G. Wiśniowieckiej pozostały bez żadnego odzewu ze strony wyższych władz zgromadzenia ${ }^{32}$. W jej kompetencjach leżała za to obsada wakujących kanonii. Prawo opiniowania tych wyborów zachowała jednak Akademia Zamojska. G. Wiśniowiecka za wszelką cenę usiłowała zminimalizować wpływ tej instytucji w tym zakresie. Na przykład w zamian za popieranie jej decyzji obiecywała profesorom różne beneficja ${ }^{33}$.

Nie wszystkimi sprawami księżna zajmowała się osobiście. Wiadomo, iż przynajmniej przez pewien okres H. Żaboklicki w jej imieniu czuwał nad przebiegiem rozpraw w Trybunale Zamojskim. Tak było chociażby w marcu 1666 r., kiedy toczył się proces związany ze skargą obywatela lwowskiego Sakchara Wartyresowicza, któremu mieszkaniec Zamościa Jan Takiesowicz był winien „440 talarów lewkowych i 1200 złotych węgierskich”. Chorąży bracławski wydał B. Rudomiczowi zgodę na pośrednictwo w tym konflikcie ${ }^{34}$.

Rozległe uprawnienia H. Żaboklickiego były powodem obaw wielu mieszkańców Ordynacji o swój stan posiadania. W kwietniu 1666 r. chorąży bracławski przywłaszczył sobie część pola należącą do B. Rudomicza, który przebywał w tym czasie w Warszawie, obserwując rozwój sprawy rywalizacji o Ordynację przed sądem sejmowym. Autor pamiętnika 28 maja przeprowadził poważną rozmowę z Żaboklickim, w wyniku której adherent księżnej po kłótni stwierdził: „Bodaj mię piorun trzasł, jeślim to malevole uczynił, i tą intencyją, żebym coraz dalej miał pomykać granice, ale żebym się odgraniczył już raz od Waszmości. Ale jednak, jeśli w tym krzywdę waszmość pretendujesz, tedy ja to, jakim chcesz sposobem, nagrodzić jestem gotów, iż kontent cale będziesz, tylko Waszmość nie trać serca do mnie".

Rudomicz jednak nie poczuł się tym usatysfakcjonowany. W swoim diariuszu stwierdził, iż chętnie poszedłby z tą sprawą do sądu, ale ma świadomość swojej niższości, gdyż „wola wszystkich osób urzędowych i prywatnych całkowicie od jego (Żaboklickiego - M.G.) skinienia zawisła”. Wobec tego zdecydował się załatwić sprawę przy pomocy pertraktacji

\footnotetext{
29 Nominacja H. Tyczoniowica na parafię w Biszczy, Zamość 20 II 1666, APL, Sąd Komisarski Zamku Zamojskiego 1, s. 194.

30 B. Rudomicz, op. cit., s. 190.

31 Ibidem, s. 201.

32 Ibidem, s. 140.

33 Ibidem, s. 142.

34 Ibidem, s. 74-76.
} 
z chorążym bracławskim, a także uciekając się do mediatorów. Zostali nimi: A. Abrek, J. Unikowski, J. Sieprawski i Sebastian Dobraszowski.

Na skutek ich interwencji 30 maja Żaboklicki przeprosił Rudomicza za całe zajście i ofiarował autorowi pamiętnika pięć korcy jęczmienia, dwa korce pszenicy, trzy korce tatarki, osiem starych owiec i tyleż samo jagniąt. Poszkodowany przyjął jednak ten dar jedynie z szacunku dla chorążego bracławskiego. Słusznie spodziewał się, iż nie odzyska należnej mu ziemi do końca życia. Żaboklicki przekroczył swoje uprawnienia także rok później, kiedy wypasał swoje stada na łąkach należących do B. Rudomicza. Jakby tego było mało, we wrześniu 1668 r. chorąży bracławski polecił wykopać rów w polu pamiętnikarza „obok drogi prowadzącej do bramy jego (Żaboklickiego - M. G.) dworu, a na tę drogę również cześć [...] pola (B. Rudomicza - M. G.) zabrano"35. Można się domyślać, iż tego typu przypadków rozmaitych nadużyć ze strony urzędników księżnej Gryzeldy było wówczas na terenie Ordynacji więcej. Jej zwykli mieszkańcy mieli bardzo ograniczone możliwości bronienia się przed nimi. Trafnie ujął ten fakt odnoszący się do swojej krzywdy B. Rudomicz: „Ponieważ inaczej nie mogę się bronić przeciwko temu bezprawiu dlatego proszę Pana, aby sam był sędzią i rozjemcą"36. O wysokiej pozycji H. Żaboklickiego świadczy też fakt, iż mieszkańcy Ordynacji, np. Marianna Mafetowa, pisali do niego rozmaite prośby. Jednakże w przypadku tej ostatniej suplika pozostała bez odpowiedzi. Mafetowa zwróciła się więc z osobistą prośbą do księżnej ${ }^{37}$. Niestety, nie wiadomo, jaki był skutek tego działania ani też czego dokładnie cała sprawa dotyczyła.

Panujący w majątkach ordynackich chaos pogłębiał fakt, iż przez ich teren przechodziły w 1666 r. jednostki wojskowe, które pod wodzą Sobieskiego miały niebawem połączyć się z szykowanymi do walki z Jerzym Sebastianem Lubomirskim oddziałami królewskimi. Jak jednak odnotował B. Rudomicz, ,żołnierze przechodząc przez wioski i osiedla nie wyrządzają żadnych krzywd"38, co było niewątpliwie zjawiskiem korzystnym dla mieszkańców Ordynacji.

W kwietniu 1666 r. księżna wydała dekret, na mocy którego każdy burmistrz miejski miał kontrolować szafarzy zbierających podatki od miejscowej ludności ,aby się żaden nie tykał pieniędzy miejskich i onymi nie dysponował" ${ }^{39}$. W razie ujawnienia takiego czynu winowajca musiał zapłacić sto grzywien kary. Nie zapobiegło to jednak licznym nadużyciom, które miały miejsce m.in. w Tomaszowie Lubelskim. Tamtejsza ludność w drugiej połowie 1666 r. skarżyła się na szafarzów, iż „dekretu [...] nie szanują. Pieniądze sami wybierają, onymi szafują, dysponują" ${ }^{90}$. Cała sprawa trafiła dnia 12 września przed Sąd Komisarski Zamku Zamojskiego. Orzekł on, że rachunki miejskie nie były w sposób należny prowadzone i że do nadużyć faktycznie dochodziło. Wobec tego każdy z winnych szafarzy musiał zapłacić

\footnotetext{
35 Ibidem, s. 95-97.

36 Ibidem, s. 146.

37 M. Mafetowa do G. Wiśniowieckiej, AGAD, AZ 1009, s. 1.

38 B. Rudomicz, op. cit., s. 97. O gromadzeniu przez Sobieskiego jednostek wojskowych w okolicach Kazimierza Dolnego zob. M. Nagielski, Druga wojna domowa w Polsce. Z dziejów polityczno-wojskowych Rzeczypospolitej u schytku rzadów Jana Kazimierza Wazy, Warszawa 2011, s. 278.

39 Dekret Sądu Komisarskiego Zamku Zamojskiego, 12 IX 1666, APL, Sąd Komisarski Zamku Zamojskiego I, s. 121

40 Ibidem.
} 
po sto grzywien. Gdyby przyłapano ich na podobnym wykroczeniu w przyszłości, to kara miałaby być dwa razy większa ${ }^{41}$.

Wyrok ten, aczkolwiek z punktu widzenia moralnego pozytywny, nie oznaczał jednak, iż w Ordynacji panował w tym czasie taki sam porządek prawny, jaki miał miejsce wcześniej. Sprawy pomiędzy mieszczanami powinny być sądzone przez Trybunał Zamojski dla miast. Tymczasem w 1666 r. nie zbierał się on praktycznie w ogóle. Wspomniane powyżej procesy były sądzone przez Sąd Komisarski Zamku Zamojskiego ${ }^{42}$. Było to jawne przeciążanie najwyższej instancji sądowniczej w Ordynacji, jaką był ten sąd, sprawami niższego rzędu. Na początku 1667 r. Trybunał Zamojski wznowił jednak swoją pracę, co wiązało się z powrotem do zwyczajnego stanu rzeczy ${ }^{43}$.

Księżna Gryzelda, tak jak wcześniej żyjący ordynaci, ingerowała osobiście w sądownictwo Ordynacji. W sierpniu 1668 r. w Trybunale Zamojskim toczyła się sprawa napadu obywateli zamojskich - niejakiego Blocha i Huntera, na bezbronnego Kobeckiego. G. Wiśniowiecka zawiesiła wydany w tej sprawie wyrok na kilka dni, co strony wykorzystały w celu pogodzenia się. Z kolei 3 września także z inicjatywy wdowy po J. Wiśniowieckim Trybunał Zamojski darował karę śmierci Ratowskiemu i Kamińskiemu, którzy byli winni zgwałcenia Zofii Staniszewskiej. Obciążono ich opłatą w wysokości 100 grzywien i 160 florenów. W celu pokrycia kosztów procesu nakazano im także zapłacić dodatkowe 12 florenów. Za namową B. Rudomicza księżna zmieniła jednak swoją decyzję, skazując winowajców na „pół roku więzienia bez chłosty i kajdan" ${ }^{\prime 4}$.

Księżna interesowała się również procesami, które miały miejsce w Sądzie Komisarskim Sądu Zamojskiego. W marcu 1669 r. wyraziła zgodę na wymianę posiadłości pomiędzy Janem Watsonem a Malinem ${ }^{45}$. Aktywność ta nie może dziwić, gdyż wspomniany sąd był praktycznie najwyższą instancją wymiaru sprawiedliwości w Ordynacji. Jako ciekawostkę można jeszcze wspomnieć fakt, iż w najbliższym otoczeniu księżnej planowano zmianę nazwy Trybunału Zamojskiego, ,aby się nie wydawało, że one (sądy - M.G.) potwierdzają ordynację zamojską"46. Do realizacji tego postulatu jednak nie doszło.

Księżnej w trakcie zarządzania dobrami Ordynacji przyszło też zmierzyć się z najazdem zewnętrznym. Pod koniec 1666 r. po klęsce dywizji Sebastiana Machowskiego pod Braiłowem południowe ziemie Rzeczypospolitej stanęły otworem dla Tatarów i wspierających ich Kozaków hetmana Piotra Doroszenki. Na skutek ich ataku na Wołyń tamtejsza szlachta

\footnotetext{
41 Ibidem, s. 121-122.

42 B. Rudomicz, op. cit., s. 101. To spostrzeżenie potwierdza brak w zespole archiwalnym Trybunału Zamojskiego dokumentów dla tego czasu. Zob. też przykładowa sprawa pomiędzy mieszczanami w Sądzie Komisarskim Zamku Zamojskiego, Sprawa Radaskiewicza, Zamość 5 V 1666, APL, Sąd Komisarski Zamku Zamojskiego 1, s. 103. Więcej o sądownictwie w Ordynacji zob. M. L. Klementowski, Sądownictwo wyższe Ordynacji Zamojskiej jako swoisty wizerunek styku różnorodnych kultur prawnych międzyrzecza Wisty i Bugu w XVI do XVIII wieku, w: Między wschodem a zachodem, cz. 1, Kultura umysłowa, red. J. Kłoczowski, Warszawa 1989, s. 291-301.

43 B. Rudomicz, op. cit., s. 127. Nie zachowały się dla tego czasu żadne rejestry spraw, które miały miejsce w Trybunale Zamojskim.

44 Ibidem, s. 194-195, 197. O tym procesie i o wcześniejszym ingerowaniu Ordynatów w sądownictwo wspominają T. Szymański, W. Froch, Materiały do dziejów sądownictwa zamojskiego II połowy XVII wieku, „Palestra”, 24(1980), nr 7, s. 115.

45 Wyrok w sprawie miedzy Watsonem a Malinem, Zamość 16 III 1669, APL, Sąd Komisarski Zamku Zamojskiego 2, k. 77-77v; B. Rudomicz, op. cit., s. 227.

46 B. Rudomicz, op. cit., s. 228.
} 
uciekła do najpotężniejszej twierdzy w najbliższej okolicy, którą był bez wątpienia Zamość. W okolicach Bełza napastnicy mało co nie wzięli do niewoli S. Koniecpolskiego i Dymitra Wiśniowieckiego.

Najazdowi uległy także ziemie Ordynacji. Część zagarniętego przez Tatarów jasyru odbiły jednak prywatne oddziały G. Wiśniowieckiej. Według B. Rudomicza prawdopodobnie pokonały one napastników w trzech miejscach. Wśród odbitych miało znaleźć się sporo zakonników i kobiet. Trzeba jednak wziąć pod uwagę fakt, iż na tereny Ordynacji dotarły wówczas zaledwie niewielkie grupy Tatarów, gdyż największa ich cześć grasowała na Ukrainie i Podolu ${ }^{47}$. Pamiętnikarz nic nie wspomina o zniszczeniach w trakcie tego najazdu. Nie wskazują też na nie zachowane inwentarze dóbr ordynackich z omawianego okresu $^{48}$. Można zatem założyć, że ich nie było lub miały miejsce w bardzo niewielkim stopniu. Choć wspomniany najazd nie był dużym zagrożeniem dla Ordynacji, to jednak należy stwierdzić, że księżna i jej żołnierze sobie z nim poradzili. Tatarzy najechali także okolice ziem majoratu niespełna rok później podczas kampanii podhajeckiej. Jednak wówczas było ich jeszcze mniej niż pod koniec 1666 r. i praktycznie w ogóle nie przekroczyli granic majątku ${ }^{49}$. W związku z tym najazdem szlachta ziemi chełmskiej 19 października $1667 \mathrm{r}$. nakazała księżnej dostarczyć ludzi z Ordynacji do wyprawy pospolitego ruszenia „według łanów poborowych z należytym apparamentem i rynsztunkiem wojskowym”. Rekruci mieli stawić się pod Stężyczkę ${ }^{50}$. Uchwała nie została jednak wykonana, gdyż pod Podhajcami podpisano porozumienie kończące działania wojenne ${ }^{51}$.

W związku z bardzo zdecydowaną polityką prowadzoną przez wdowę po J. Wiśniowieckim na terenie Ordynacji mieszczanie zamojscy wystosowali do niej pod koniec lutego 1667 r. specjalną suplikę. Księżna przyjęła ją bardzo niechętnie. Ostrzegła, że wszelkie próby siłowego pozbawienia jej władzy będzie karać z największą surowością ${ }^{52}$. Jakieś bliżej nieznane skargi poddanych miały też miejsce w $1668 \mathrm{r}$. Wspomina o nich jeden z arendarzy księżnej, Jerzy Leśniowski, deklarując jej przy tym swoją wierność i uległośćs ${ }^{53}$.

Nie oznacza to jednak, iż księżna nie reagowała na żadne prośby zwykłych obywateli. W pierwszych miesiącach 1667 r. wniósł do niej prośbę młynarz ze wsi Złojec-Stanisław Malik. Domagał się, aby G. Wiśniowiecka pozwoliła mu osiedlić się na części ziemi, która wcześniej należała do jego ojca. Księżna przychyliła się do tego postulatu. Wspomniane dziedzictwo młynarz miał w przyszłości ,zabywać z potomkami swymi bez wszelakiej przeszkody"54. S. Malik miał z tytułu użytkowania tej ziemi płacić czynsz, jednak zachowywał prawo jej wykupu, a tym samym zwolnienie z obowiązku uiszczania tej należności ${ }^{55}$.

47 Ibidem, s. 123, 126. Więcej o wydarzeniach pod Braiłowem i o zasięgu ataku kozacko-tatarskiego zob. L. Podhorodecki, Chanat krymski i jego stosunki z Polska w XV-XVIII w., Warszawa 1987, s. 205.

48 Inwentarze włości szczebrzeskiej z lat 1666 i 1667, APL, Archiwum Ordynacji Zamojskiej (dalej: AOZ) 42, s. $60-667$.

49 B. Rudomicz, op. cit., s. 158.

50 Laudum sejmiku ziemi chełmskiej, Chełm 19 X 1667, w: Akta sejmikowe ziemi chetmskiej 1572-1668, oprac. W. Bondyra, H. Gmiterek, J. Termes, Lublin 2013, s. 638-639.

51 Więcej o kampanii podhajeckiej i o zawartym porozumieniu zob. W. Majewski, Podhajce - letnia i jesienna kampania 1667 r., „Studia i Materiały do Historii Wojskowości”, 1960, t. 6, z. 1, s. 47-99.

52 B. Rudomicz, op. cit., s. 132; I. Czamańska, op. cit., s. 227.

53 J. Leśniowski do G. Wiśniowieckiej, 1668, AGAD, AZ 1008, s. 1.

54 Dekret księżnej w sprawie S. Malika, Zamość 22 IV 1667, APL, Sąd Komisarski Zamku Zamojskiego 1, s. 130.

55 Ibidem. 
W maju 1669 r. księżna zezwoliła Zofii Makowieckiej na wykup (jego cena wynosiła 110 zł) dwóch półłanków pola, które należały wcześniej do zmarłego Macieja Makowieckiego. Mogły być one odebrane potomkom owej mieszkanki Ordynacji pod warunkiem zwrócenia im powyższej kwoty ${ }^{56}$. Znane są także inne prośby kierowane przez poddanych do G. Wiśniowieckiej ${ }^{57}$. Nie znany jest jednak ich rezultat.

W maju 1667 r. wśród nowo mianowanych kanoników powstał spór o pierwszeństwo w ławach w prezbiterium, co miało znaczenie przede wszystkim prestiżowe. A. Abrek prywatnie obiecał pierwszeństwo Janowi Chryzostomowi Budzyńskiemu. Na skutek protestu akademii otrzymał je jednak ks. Jan Różeński. W całą sprawę wmieszała się ostatecznie księżna Wiśniowiecka, która poleciła przyznać pierwsze miejsce Budzyńskiemu. Decyzja ta, choć podjęta jednoosobowo, została jednak wcielona w życie. Nie może dziwić, iż część mieszkańców Ordynacji wypowiadała się o niej krytycznie. Rudomicz stwierdził, iż „należy (wobec tego - M. G.) wnioskować, jakie jest znaczenie Akademii, kiedy jedna osoba decyduje za wszystkich" 58 .

Nie można odmówić księżnej podejmowania starań o zapewnienie porządku w Ordynacji. Trudniejsze rozprawy sądowe starała się zlecać wybranym przez siebie osobom. Tak było np. $z$ toczącą się w sądzie wójtowskim sprawą starej wieśniaczki ze Żdanowa. Była ona podejrzana o kradzież Najświętszego Sakramentu z jednego z kościołów. Nie było jednak przeciwko niej żadnych dowodów. Księżna na przełomie czerwca i lipca 1667 r. powierzyła rozstrzygnięcie tej sprawy B. Rudomiczowi. Stwierdził on, że tak naprawdę winna temu przestępstwu (jak i innym) jest osoba, która doniosła na staruszkę. Prawdziwa sprawczyni zamieszania została więc stosownie ukarana ${ }^{59}$. Z kolei miesiąc później Rudomicz rozpatrywał sprawy w Sądzie Komisarskim Zamku Zamojskiego, za co księżna Gryzelda, chcąc zapewne po wypadkach z H. Żaboklickim nieco bardziej przekonać go do swojej osoby, poleciła wypłacić mu stosowną nagrodę ${ }^{60}$. Planowała doprowadzić do jego wyboru na wójta albo na rajcę zamojskiego. Lecz autor pamiętnika wymówił się od tego funkcją asesora w Trybunale Zamojskim.

Rudomicz pobierał wówczas roczną pensję w wysokości 200 zł. Nie otrzymał jej jednak za 1666 i 1667 r. S. Borkowski zapewniał go jednak, ,że będzie ona wypłacana w przyszłości z woli j. ośw. księżny”61. Potwierdzili to J. Unikowski i A. Wacławowicz ${ }^{62}$. Świadczy to niewątpliwie o kłopotach finansowych, z jakimi księżna borykała się nie tylko przez cały okres władania Ordynacją, ale także przez sporą część swojego życia. Mimo to Rudomicz na przełomie lat 1667/68 otrzymał zaległe wynagrodzenie. Księżna tym posunięciem wyraźnie zwiększyła sobie jego sympatię. Od tej pory zaczął on z większym szacunkiem odnosić

\footnotetext{
56 Zezwolenie księżnej na wykup ziemi, Zamość (data dzienna nieczytelna) V 1669, APL, AOZ, Biblioteka Ordynacji Zamojskiej 1348, bez paginacji.

57 W. Panas do G. Wiśniowieckiej, Archiwum Narodowe w Krakowie, Zbiór Zygmunta Glogera 448, s. 3; S. Nowyk do G. Wiśniowieckiej, AGAD, AZ 1012, s. 1; Skarga na Zubrzyckiego, sługę G. Wiśniowieckiej, AGAD, AZ 1023, s. 1 .

58 B. Rudomicz, op. cit., s. 141.

59 Ibidem, s. 147.

60 Ibidem, s. 152.

61 Ibidem, s. 168.

62 Ibidem.
} 
się także do jej stronników ${ }^{63}$. Wdowa po J. Wiśniowieckim wykazała się w tym wypadku dużym wyczuciem politycznym, gdyż w maju 1668 r. Rudomicz został wybrany rektorem Akademii Zamojskiej ${ }^{64}$. Nie było tajemnicą, iż G. Wiśniowiecka starała się mieć wpływ na tę instytucję. Dotyczyło to przede wszystkim jej wykładowców. Niechętnie np. wyraziła zgodę na dłuższy wyjazd Adriana Krobskiego do Krakowa, co wiązało się z niemożnością pełnienia przez niego funkcji wykładowcy analogii ${ }^{65}$. Będąc jednak świadoma prestiżu, jaki mogła zdobyć w całej Rzeczypospolitej dzięki tej uczelni, wspierała jej rozwój, co przyczyniło się do znaczącego wzrostu poziomu nauczania w Akademii Zamojskiej w stosunku do poprzednich lat ${ }^{66}$.

Początek 1668 r. to okres prezentowania dużej pewności siebie zarówno przez księżnę jak też jej zwolenników. Ci ostatni zaczęli wówczas rozpuszczać fałszywe pogłoski, iż rywalizacja o Ordynację została już zakończona i że G. Wiśniowiecka otrzymała prawo dożywotniego władania wspomnianym majątkiem ${ }^{67}$. Choć nie była to prawda, to jednak sporo mieszkańców Ordynacji, z racji braku innego źródła informacji, musiało w ten przekaz uwierzyć. Tym samym uprawomocniało to rządy księżnej w oczach poddanych. Od tej chwili każdy chaos panujący na terenie majoratu mógł być uzasadniany wrogim działaniem Zamoyskich. Tak było np. w marcu 1668 r., kiedy to bramy Zamościa były zamykane rzekomo z powodu ich złych zamiarów ${ }^{68}$. W tym czasie nie mieli jednak oni na tyle silnej pozycji, by planować jakikolwiek zbrojny atak na Ordynację. Nie znany jest zatem prawdziwy powód takiego postępowania. Prawdopodobnie chodziło po prostu o bezpieczeństwo miasta, choć nie można też wykluczyć motywów propagandowych.

Księżna ingerowała także w zabudowę Zamościa. W lipcu 1668 r. z jej upoważnienia M.A. Wacławowicz razem z magistratem miejskim dokonali wydzielenia tylnej części zabudowań podwórza za kamienicą, w której mieszkał B. Rudomicz. Wszystkie znajdujące się tam ,zawalidrogi jak kloaka pana (Jana - M. G.) Wilczka, chlewik pani Sułtanowej i inne polecono zburzyć"69. Z inicjatywy G. Wiśniowieckiej (i za pośrednictwem M.A. Wacławowicza) w maju 1669 r. przeprowadzono remont budynku prepozytury przy kaplicy Przemienienia Pańskiego w Zamościu. Rudomicz określił to jako „cel słuszny i zbożny”70.

$\mathrm{Z}$ biegiem czasu pamiętnikarz zdobywał coraz większy wpływ na G. Wiśniowiecką. Pod koniec września 1668 r. namówił księżną do zmiany składu sędziowskiego sprawy o zabójstwo. Pierwotnie chciała ona do niej wytypować B. Rudomicza. Jednakże za jego namową sędzią w tym procesie został ostatecznie, ze względu na swoją surowość w wydawanych wyrokach, Aleksander Garczyński ${ }^{71}$. Autor diariusza nie uniknął jednak funkcji sędziego

63 Ibidem, s. 171. Pamiętnikarz np. wspomina, iż 1 I 1668 „pił umiarkowanie u Pana Wacławowicza”. Następnego dnia zaś ucztował w gronie zwolenników księżnej Gryzeldy. Z kolei w marcu 1668 r. otrzymał informację, iż „księżna jest dla niego życzliwa”. Życzył sobie, aby „Pan tę życzliwość pomnażał”. Zob. ibidem, s. 176. O kłopotach finansowych księżnej zob. I. Czamańska, op. cit., s. 218-224.

${ }_{64}$ B. Rudomicz, op. cit., s. 181.

65 Ibidem, s. 169.

66 Ibidem, s. 205-206. Więcej na temat rozwoju akademii zob. J. K. Kochanowski, Dzieje Akademii Zamojskiej (1594-1784), Kraków 1899-1900, s. 128-132.

67 B. Rudomicz, op. cit., s. 172.

68 Ibidem, s. 176.

69 Ibidem, s. 191.

70 Ibidem, s. 239.

71 Ibidem, s. 199. 
w tego typu sprawie na początku marca 1669 r. Przyjął ją, bo taka była wola księżnej. Uczynił to jednak dość niechętnie. Proces dotyczył zabójstwa popełnionego w Turobinie przez niejakiego Pawła. Miał on zabić za to, że został nazwany oszustem. Pomogła mu w tym jego żona, której jednak udało się zbiec z miejsca zdarzenia ${ }^{72}$. Koniec tej sprawy niestety nie jest znany.

Po sejmie konwokacyjnym 1668 r. coraz większe znaczenie w Ordynacji zaczął zdobywać M. Wiśniowiecki. Rudomicz wspomina, iż w listopadzie tego roku kilkakrotnie odwiedził go biskup chełmski Jan Różycki ,jako kandydata do korony polskiej prosząc go o pamięćc"73. Z kolei w wigilię Bożego Narodzenia syn G. Wiśniowieckiej wyprawił wystawną ucztę, na którą zostało zaproszonych wiele osób, w tym wszyscy stronnicy księżnej ${ }^{74}$. Ponadto w kwietniu i maju 1669 r. wraz z jej sługą, niejakim Białobłockim, miał znaczny udział w przyprowadzeniu na miejsce zbiórki pospolitego ruszenia ziemi chełmskiej tych mieszkańców Ordynacji, którzy stali się jego częścią na czas elekcji nowego króla, na co G. Wiśniowiecka bez żadnych oporów wyraziła zgodę ${ }^{75}$.

Księżna Gryzelda Wiśniowiecka prowadziła w latach 1666-1669 twardą politykę w Ordynacji. Sprawowała rządy silną ręką. Miało to zapobiec nie tylko przestępstwom, ale także wystąpieniom zewnętrznym. Tyczyło się to zwłaszcza ewentualnych zamieszek, które mogły być inspirowane przez Zamoyskich. Przeciwko nim na terenie Ordynacji cały czas działała propaganda. Księżna nie tylko ją wspierała, ale także często inspirowała. Jej celem było skłonienie miejscowej ludności do akceptacji rządów G. Wiśniowieckiej i wspomagania jej w konflikcie z kasztelanem czernihowskim i podstolim lwowskim, co udało się osiągnąć. Drugą osobą, która miała olbrzymi wpływ na sposób sprawowania władzy w Ordynacji, był chorąży bracławski H. Żaboklicki. Znamienne jest, iż w prowadzonej na terenie majoratu polityce nie mieli udziału zaangażowani w konflikt o Ordynację S. Koniecpolski i M. Wiśniowiecki, co było spowodowane ich młodością i niedużym doświadczeniem politycznym. Znaczenie tego ostatniego zaczęło wzrastać dopiero po sejmie konwokacyjnym w $1668 \mathrm{r}$.

Pozycja Michała Korybuta Wiśniowieckiego stała się jeszcze większa, kiedy to 19 czerwca 1669 r. został on wybrany na króla w Rzeczypospolitej. Jest to już jednak temat na osobne studium.

\section{Bibliografia}

\section{Źródła rękopiśmienne}

Archiwum Główne Akt Dawnych w Warszawie: Archiwum Zamoyskich: nr 1000, 1002, 1008, 1009, 1012, 1019, 1023, 2379, 2595, 2750.

Archiwum Narodowe w Krakowie: Zbiór Zygmunta Glogera: nr 448.

Archiwum Państwowe w Lublinie: Akta miasta Zamościa: nr 127.

Archiwum Ordynacji Zamojskiej: nr 42, Biblioteka Ordynacji Zamojskiej nr 1348.

Księgi grodzkie krasnostawskie: RMO nr 5.

\footnotetext{
72 Ibidem, s. 225.

73 Ibidem, s. 207.

74 Ibidem, s. 212.

75 Laudum sejmiku ziemi chełmskiej, 8 IV 1669, Nacyjanalny gistaryczny archiv Biełarusi w Mińsku, f. 1740, t. 7, k. 105v-106; G. Wiśniowiecka do szlachty ziemi chełmskiej, V 1669, AGAD, AZ 1000, s. 1; Uniwersał G. Wiśniowieckiej do obywateli powiatu szczebrzeskiego względem pospolitego ruszenia, Warszawa 14 VI 1669, APL, Sąd Komisarski Zamku Zamojskiego 2, s. 98.
} 
Sąd Komisarski Zamku Zamojskiego: nr 1, 2.

Centralnyj Derżawnij Istorićnij Archiv Ukraini we Lwowie: f. 9, op. 1, ks. 420.

Nacyjanalny gistaryczny archiv Biełarusi w Mińsku: f. 1740, op. 1, ks. 7.

\section{Źródla drukowane}

Akta sejmikowe ziemi chetmskiej 1572-1668, oprac. W. Bondyra, H. Gmiterek, J. Termes, Lublin 2013.

Rudomicz B., Efemeros czyli diariusz prywatny pisany w Zamościu w latach 1656-1672, cz. 2, 1665-1672, oprac. W. Froch, M. L. Klementowski, Lublin 2002.

Testament Gryzeldy Konstancji z Zamoyskich Wiśniowieckiej z 1672 roku, oprac. K. Przyboś, „Genealogia”, 2003, t. 15, s. 101-106.

\section{Opracowania}

Chmielewska M., Sejm elekcyjny Michała Korybuta Wiśniowieckiego 1669 roku, Warszawa 2006.

Czamańska I., Wiśniowieccy. Monografia rodu, Poznań 2007.

Klementowski M. L., Sądownictwo wyższe Ordynacji Zamojskiej jako swoisty wizerunek styku różnorodnych kultur prawnych międzyrzecza Wisty i Bugu w XVI do XVIII wieku, w: Między wschodem a zachodem, cz. 1, Kultura umysłowa, red. J. Kłoczowski, Warszawa 1989.

Kochanowski J. K., Dzieje Akademii Zamojskiej (1594-1784), Kraków 1899-1900.

Leszczyński R., Rudomicz Bazyli, w: Polski Słownik Biograficzny, t. 32, Warszawa 1991.

Majewski W., Podhajce - letnia i jesienna kampania 1667 r., „Studia i Materiały do Historii Wojskowości”, 1960, t. 6, z. 1, s. 47-99.

Matyasik J., Obóz polityczny króla Michała Korybuta Wiśniowieckiego, Warszawa 2011.

Nagielski M., Druga wojna domowa w Polsce: z dziejów polityczno-wojskowych Rzeczypospolitej u schytku rządów Jana Kazimierza Wazy, Warszawa 2011.

Partyka W., Żydowscy lekarze i cyrulicy w Ordynacji Zamojskiej w XVII-XVIII w., „Kwartalnik Historii Żydów”, 2008, nr 2(226), s. 313-317.

Podhorodecki L., Chanat krymski i jego stosunki z Polska w XV-XVIII w., Warszawa 1987.

Sokalski M., Między królewskim majestatem a szlachecka wolnością. Postawy polityczne szlachty małopolskiej w czasach Michała Korybuta Wiśniowieckiego, Kraków 2002.

Szymański T., Froch W., Materiały do dziejów sądownictwa zamojskiego II połowy XVII wieku, „Palestra”, 24(1980), nr 7, s. 100-131.

Tyszka P., Maria Kazimiera d'Arquein Zamoyska, czwarta ordynatowa zamojska, w: Maria Kazimiera Sobieska (1641-1716). W kręgu rodziny, polityki i kultury, red. A. Kalinowska, P. Tyszka, Warszawa 2017, s. 10-44. 